\title{
Szakmai vezetőknek 1 percben: Az Európai Alkohol Akcióterv végrehajtása ${ }^{1}$
}

\author{
For professional leaders in 1 minute: Implementing the \\ European Action Plan on Alcohol
}

$\begin{array}{ll}\text { Ismertető: } & \text { Devosa Iván } \square \\ & \text { Neumann János Egyetem, Pedagógusképző Kar, Egészségtudományi és } \\ & \text { Egészségfejlesztési Kutatócsoport }\end{array}$

Beküldve: $\quad$ 2020.01. 20.

doi: $\quad$ 10.24365/ef.v61i1.557

Nyolc évvel a 2012-2020-as Európai Alkohol Akcióterv (European Action Plan on Alcohol 2012-2020, EAPA) elfogadása után a többi régióhoz viszonyítva a WHO Európai Régiójában a legelterjedtebb az alkoholfogyasztás, az alkalmi nagyivás, legmagasabb az egy före jutó alkoholfogyasztás, valamint legalacsonyabb az absztinensek aránya. Minden negyedik fiatal felnőtt (20-24 évesek) halálát az alkoholfogyasztás okozza, ami jelentős mértékben hozzájárul az egészségegyenlőtlenségekhez is.

A WHO szerint a legjobb árazási gyakorlatot (best buy pricing) kitűző szakpolitikai intézkedések segíthetik elő legköltséghatékonyabban a prevenciót és a nem fertőző betegségek megelőzését.'

Az EAPA végrehajtási tervének 2019-es értékelése szerint a tíz kulcsterületen elért eredmények országonként igen különbözőek, legrosszabbul az árképzésre irányuló szakpolitikák teljesítettek. Az alkoholhoz való hozzáférés szigorítása (minimális korhatár emelése és az üzletek nyitvatartási idejének módosítása), valamint a reklámozás szabályozása jelentősen csökkentheti az alkoholfogyasztással kapcsolatos problémákat, ám a szabályozás mértéke országonként jelentősen eltér. A szeszes italok reklámozását Litvániában teljesen betiltották, más országokban csak önkéntes iparági szabályozás létezik. Hatalmas kihívás a digitális kommunikáció gyors fejlődése, főként a közösségi médiatartalom mögött felmerülő kereskedelmi érdekek felismerésének nehézsége. Finnország egyedüliként szabályozta a közösségi médiában megjelenő reklámokat és az online marketinget. A gyorsan változó online világ szabályozása kihívást jelent a döntéshozóknak, és a nemzeti jogszabályok gyakran késve jelennek meg. A digitális kereskedelmi kommunikáció sok szempontja még mindig ismeretlen a politikai döntéshozók és a népegészségügyi szakemberek számára.

Csak néhány európai országban követi az alkoholra kivetett adó mértéke az infláció változását. Annak ellenére, hogy a minden termékre kiterjedő alkoholtartalomalapú adóztatás egyaránt hatékonyan javíthatná az egészségi állapotot és csökkenthetné az egészségegyenlőtlenségeket, egyetlen tagállam sem alkalmazza ezt a megoldást. Léteznek innovatív intézkedések is, mint a minimális egységár bevezetése.

Az EAPA 2012-2020 végrehajtásáról és eredményeiről folytatott konzultáción kiemelték egy új

\footnotetext{
' A legjobb árazási gyakorlatok közé az alábbiak tartoznak: szeszes italok jövedéki adójának növelése, literenkénti egységár bevezetése, az árusításhoz kapcsolódó kedvezmények szabályozása (pl. az átalánydíjért történő korlátlan fogyasztás tiltása), reklámozás korlátozása, promóciós és szponzortilalom bevezetése. További információk: European action plan to reduce the harmful use of alcohol 2012-2020. Copenhagen, WHO Regional Office for Europe, 2012. http://www.euro.who.int/en/health-topics/disease-prevention/alcohol-use/publications/2012/european-action-plan-toreduce-the-harmful-use-of-alcohol-20122021
} 
ütemterv bevezetésének szükségességét, ami megerősíti az országos szintű végrehajtást, valamint a tagállamokat támogatja olyan népegészségügyileg fontos kötelezettségvállalásaik elérésében, mint

\section{HIVATKOZÁSOK}

a nem fertőző betegségek előfordulásának csökkentése és az ENSZ Fenntartható Fejlődési Céljainak megvalósítása.

${ }^{1}$ Goiana-da-Silva F, Cruz-e-Silva D, Lindeman M, Hellman M, Angus C, Karlsson T, Renström M, Ferreira-Borges C. (2019). Implementing the European Action Plan on Alcohol. Lancet Public Health. 2019 Oct;4(10):e493.

doi: $\underline{10.1016 / S 2468-2667(19) 30174-4}$ 